\author{
KATARZYNA LIŻYŃSKA \\ ORCID: 0000-0002-9666-1019 \\ Uniwersytet Wrocławski \\ Zakład Prawa o Wykroczeniach, Karnego Skarbowego i Gospodarczego
}

\title{
O CELOWOŚCI ŚRODKÓW ODDZIAŁYWANIA WYCHOWAWCZEGO W PRAWIE WYKROCZEŃ
}

\begin{abstract}
Abstrakt: Prawo wykroczeń zawiera czyny o charakterze zarówno kryminalnym, jak i administracyjnym. Wymusza to na ustawodawcy zróżnicowany system reakcji. Obok stricte penalnych form oddziaływania na sprawcę wykroczenia kodeks wykroczeń pozwala na zastosowanie między innymi środków oddziaływania wychowawczego. Celem artykułu jest przedstawienie tych środków, kryteriów ich stosowania oraz podkreślenie potrzeby zmian w zakresie art. 41 k.w.
\end{abstract}

Słowa kluczowe: wykroczenie, środki oddziaływania wychowawczego, kara, środki pozakarne, oskarżyciel publiczny

Postępowanie w sprawach o czyny zabronione może być ukształtowane według dwóch przeciwstawnych zasad - legalizmu i oportunizmu. Zasada legalizmu oznacza obowiązek ścigania sprawcy, natomiast zasada oportunizmu uprawnienie do ścigania ${ }^{1}$. W. Radecki stwierdza, że prawo wykroczeń nie opiera się wyłącznie na którejś z tych zasad, ale bliższe jest tej drugiej. Konsekwencją jest zasada stosowania środków pozakarnych, zgodnie z którą środki te, jako forma reakcji na wykroczenia, mają pierwszeństwo przed środkami penalnymi ujętymi w kodeksie wykroczeń, a dopiero w razie uznania, że nie są one wystarczające do wdrożenia sprawcy do poszanowania prawa, należy sięgać po kary². Również T. Grzegorczyk wskazuje na preferencję, jako reakcję na wykroczenie, środków pozakarnych, zatem wymóg zareagowania uprawnionego podmiotu na wykroczenie, ale niekoniecznie ściganie sprawcy wykroczenia. Według tego autora nie mamy tutaj do czynienia z czystym oportunizmem. Nie dochodzi do nieścigania w ogóle zaistniałego wykroczenia ze względu na niecelowość, lecz zareagowanie

1 Tak W. Radecki, [w:] Kodeks wykroczeń. Komentarz, red. M. Bojarski, W. Radecki, Warszawa 2019, s. 431.

2 Tak ibidem, s. 431. 
na taki czyn w sposób przewidziany przez prawo, tyle że z sięgnięciem do środka pozakarnego ${ }^{3}$.

Należy zatem przyjąć, że wobec sprawcy wykroczenia w pierwszej kolejności powinno rozważyć się możliwość zastosowania środków pozakarnych — oddziaływania wychowawczego, a gdyby okazało się to niecelowe - wymierzyć grzywnę w drodze mandatu, przy braku negatywnych przesłanek zastosowania postępowania mandatowego, a dopiero gdy w ocenie organu taka reakcja jest niewystarczająca - skierować do sądu wniosek o ukaranie, co oznacza możliwość zastosowania reakcji ściśle karnej ${ }^{4}$. Takie rozwiązanie związane jest przede wszystkim ze specyfiką prawa wykroczeń, które oprócz typowych czynów kryminalnych penalizuje także czyny porządkowe (administracyjne), co powoduje zróżnicowaną reakcję na te czyny.

J. Jakubowska-Hara wskazuje, że sam termin ,oddziaływanie wychowawcze” może budzić wątpliwości nie tylko w związku z jego nieokreślonością, ale przede wszystkim z powodu nie zawsze uzasadnionej wiary ustawodawcy w wychowawcze możliwości wielu reakcji przewidzianych w prawie wykroczeń. Według autorki przypisywanie niektórym, także penalnym, środkom funkcji wychowawczej jest raczej złudnym i niemożliwym do weryfikacji założeniem ${ }^{5}$. Nie należy jednak zapominać, że przecież jedną z dyrektyw wymiaru kary jest cel wychowawczy, w którym najmocniej akcentowanym czynnikiem jest poprawa moralna skazanego - gruntowna zmiana osobowości sprawcy w kierunku uzyskania postawy społecznie dodatniej. Niezależnie zatem od ujętej nazwy — czy to „środków oddziaływania wychowawczego", czy też „środków oddziaływania pozakarnego”, czy „środków naprawczych i dyscyplinujących"6 — środki te powinny pozostać w prawie wykroczeń jako jedna $\mathrm{z}$ form reakcji na wykroczenie.

Do 1998 roku środki oddziaływania wychowawczego w Kodeksie wykroczeń oparte były na dwóch przepisach — art. 40 i $41^{7}$. Zgodnie z uchylonym w 1998 roku art. $40 \S 1$ k.w. w stosunku do sprawcy czynu można było poprzestać na zastosowaniu środków przewidzianych w regulaminie pracy, w postępowaniu dyscyplinarnym, w postępowaniu przed sądami społecznymi ${ }^{8}$ lub innych środków

3 Kodeks wykroczeń. Komentarz, red. T. Grzegorczyk, Warszawa 2010, s. 157.

4 J. Jakubowska-Hara, [w:] Reforma prawa wykroczeń, t. 1, red. P. Daniluk, Warszawa 2019, s. 309 .

5 Ibidem, s. 311.

${ }^{6} \mathrm{O}$ zmianę nazwy środków oddziaływania wychowawczego na wskazane w treści wnosi J. Jakubowska-Hara. Por. ibidem.

7 Art. 40 został uchylony ustawą z dnia 28 sierpnia 1998 roku o zmianie ustawy - Kodeks wykroczeń, ustawy — Kodeks postępowania w sprawach o wykroczenia, ustawy o ustroju kolegiów do spraw wykroczeń, ustawy — Kodeks pracy i niektórych innych ustaw (Dz.U. Nr 113, poz. 717), przepis zaś art. 41 k.w. został wówczas zmieniony.

${ }^{8}$ Wymienione w tym przepisie sądy społeczne przewidywała ustawa z 30 marca 1965 roku o sądach społecznych (Dz.U. Nr 13, poz. 92 ze zm.). Sądy społeczne, mające działać przy zakładach pracy, wskazane $\mathrm{w}$ ustawie nie zostały wprowadzone w życie, na podstawie tej ustawy powołano 
oddziaływania wychowawczego wystarczających do wdrożenia sprawcy do poszanowania prawa i przestrzegania zasad współżycia społecznego i nie kierować sprawy do organu orzekającego. Natomiast gdyby jednak przemawiał za tym uzasadniony interes społeczny, prokurator mógł skierować do organu orzekającego sprawę, w której poprzestano na zastosowaniu do sprawcy środków wymienionych w art. $40 \S 2$ k.w. Artykuł 41 k.w. w pierwotnym brzmieniu pozwalał nawet, nie wszczynając postępowania, przekazać sprawę kierownikowi zakładu pracy, w którym sprawca jest zatrudniony, jeżeli z charakteru popełnionego czynu wynikało, że jest on naruszeniem obowiązku pracowniczego, albo sądowi społecznemu lub organizacji społecznej, do której sprawca należy, z wnioskiem o zastosowanie środków przewidzianych $\mathrm{w}$ regulaminie pracy, w postępowaniu dyscyplinarnym lub innych środków oddziaływania wychowawczego, przy uznaniu, że jest to wystarczające do wdrożenia sprawcy wykroczenia do poszanowania prawa i zasad współżycia społecznego. Ze względu na zróżnicowany charakter środków wychowawczych rozwiązania te były krytykowane. Wskazywano, że niektóre z tych środków dolegliwością przewyższały uznane formalnie za penalne oraz że osoby, wobec których były one stosowane, korzystały z ograniczonych gwarancji procesowych, albowiem sprawy przekazywane były różnym podmiotom działającym na podstawie odmiennych procedur'.

W obecnym brzmieniu podstawą do stosowania środków oddziaływania wychowawczego jest art. 41 k.w., który w rzeczywistości stał się odpowiednikiem art. 40 k.w. W. Radecki zwraca uwagę, że zmiany w zakresie możliwości stosowania środków oddziaływania wychowawczego sprowadziły się do tego, że:

1. dopuszczono poprzestanie na stosowaniu środków oddziaływania wychowawczego bez żadnych rygorów, a w szczególności bez wymogu dojścia do przekonania, że są one wystarczające do wdrożenia sprawcy poszanowania prawa i przestrzegania zasad współżycia społecznego;

2. wyeliminowano możliwość kontroli prokuratorskiej nad zasadnością poprzestania na zastosowaniu środków oddziaływania wychowawczego;

3. sprecyzowano pojęcie środków oddziaływania wychowawczego;

4. wyeliminowano możliwość przekazywania spraw o wykroczenia pracodawcom i organizacjom społecznym ${ }^{10}$.

Zgodnie z obecnym brzmieniem tego przepisu organ upoważniony do złożenia wniosku o ukaranie czy do nałożenia grzywny mandatem karnym może poprzestać na: pouczeniu, zwróceniu uwagi, ostrzeżeniu, innych środkach oddziaływania wychowawczego.

natomiast społeczne komisje pojednawcze, które funkcjonowały przy terenowych ogniwach samorządowych — radach osiedlowych, gminnych — pod patronatem Frontu Jedności Narodu.

9 Tak m.in. J. Szumski, Środki penalne w polskim prawie wykroczeń na tle doświadczeń praktyki, Lublin 1995, s. 197 n.

10 W. Radecki, op. cit., s. 432-433. 
Katalog środków oddziaływania wychowawczego nie jest zamknięty. Brakuje także kodeksowej definicji środków oddziaływania wychowawczego. A. Gubiński za takie środki uważa wszelkiego rodzaju poczynania, których głównym lub ubocznym celem jest oddziaływanie wychowawcze, jeżeli obiektywnie są one zdolne (w szerszym czy węższym zakresie) realizować to zadanie ${ }^{11}$. Znajdą tu zatem zastosowanie wskazywane w uchylonym art. 40 k.w. kary dyscyplinarne, porządkowe i organizacyjne. Należy podkreślić, że środki oddziaływania wychowawczego mogą cechować się niewielką dolegliwością - w przypadku pouczenia kierowcy przez policjanta, bądź znaczną — gdy poskutkują przykładowo wydaleniem z organizacji ${ }^{12}$. A. Marek podnosi, że środkiem oddziaływania wychowawczego mogą być środki zastosowane w szkole, do której uczęszcza sprawca, w zakładzie pracy, w którym jest zatrudniony, lub w stowarzyszeniu, którego jest członkiem ${ }^{13}$. Takie rozwiązanie było ustawowo dopuszczalne przed nowelizacją z 1998 roku i już wówczas budziło uzasadnione wątpliwości ze względu na stygmatyzujący charakter tego rodzaju środków, a ponadto, zwłaszcza w przypadku młodzieży uczącej się lub studiującej, na niewspółmiernie negatywne konsekwencje w postaci kar dyscyplinarnych, którymi dysponują szkoły i uczelnie ${ }^{14}$. W. Radecki wymienia wśród środków oddziaływania wychowawczego pouczenie sprawcy wykroczenia o zasadności wpłacenia określonej kwoty na cel społeczny jako reakcji na tak zwane wykroczenie wędkarskie z ustawy o rybactwie śródlądowym ${ }^{15}$. Zarządzenie nr 323 Komendanta Głównego Policji z dnia 26 marca 2008 roku w sprawie metodyki wykonywania przez policję czynności administracyjnoporządkowych w zakresie wykrywania wykroczeń oraz ścigania ich sprawców ${ }^{16}$ wprost wskazuje, że jako środki oddziaływania wychowawczego można w szczególności stosować: 1. pouczenie, poprzez wskazanie sprawcy wykroczenia niezgodności jego zachowania z obowiązującymi przepisami, ze wskazaniem tych przepisów; 2. zwrócenie uwagi lub ostrzeżenie sprawcy, z jednoczesnym zagrożeniem ukarania go w razie ponownego popełnienia wykroczenia; 3 . przekazanie pisemnej informacji pracodawcy lub organizacji społecznej, do której sprawca należy, gdy z charakteru czynu wynika, że jest on jednocześnie naruszeniem dyscypliny służbowej, statutu organizacji, regulaminu członkowskiego itp. O zastosowaniu ,innych” niż wymienione w art. 41 k.w. środków powinny decydować okoliczności danego przypadku i cel, któremu mają one służyć, a mianowicie ich oddziaływanie wychowawcze. Należy także podkreślić, że środków oddziaływania wychowawczego można jednocześnie zastosować kilka, na przykład pouczyć

\footnotetext{
11 A. Gubiński, Prawo wykroczeń, Warszawa 1980, s. 223.

12 W. Kotowski, Kodeks wykroczeń. Komentarz, Warszawa 2009, s. 178.

13 A. Marek, Prawo wykroczeń (materialne i procesowe), Warszawa 2012, s. 94.

14 J. Jakubowska-Hara, op. cit., s. 312.

15 W. Radecki, op. cit., s. 437.

16 Dz.Urz. KGP z 2008 r. Nr 9, poz. 48.
} 
i ostrzec ${ }^{17}$. R. Krajewski słusznie jednak wskazuje, że stosowanie wobec sprawcy zbyt wielu form środków oddziaływania wychowawczego nie jest uzasadnione. Trudno byłoby za mające jakikolwiek walor uznać zachowanie funkcjonariusza policji lub innego organu, który jednocześnie pouczałby, ostrzegał oraz zwracał uwagę sprawcy. Byłoby to swoistym nadmiarem, mogącym prowadzić do niepotrzebnych zatargów między sprawcami wykroczeń a funkcjonariuszami ${ }^{18}$.

Z obecnego brzmienia art. 41 k.w. nie wynika także wprost, że zastosowanie środków oddziaływania wychowawczego jest swoistą alternatywą dla wystąpienia z wnioskiem o ukaranie do sądu. W doktrynie wprawdzie wyjaśniano, że zastosowanie tych środków powinno wiązać się z odstąpieniem od kierowania wniosku o ukaranie do sądu, jednak ustawa nie zawiera takiego unormowania ${ }^{19}$. Artykuł 61 $\S 1$ pkt 2 k.p.w. daje możliwość odmowy wszczęcia postępowania w sprawie o wykroczenie bądź jego umorzenia, jeżeli wobec sprawcy zastosowano środek oddziaływania $\mathrm{w}$ postaci pouczenia, zwrócenia uwagi lub ostrzeżenia albo środek przewidziany w przepisach o odpowiedzialności dyscyplinarnej lub porządkowej, a środek ten jest wystarczającą reakcją na wykroczenie. Jest to rozwiązanie fakultatywne. Wskazuje to na, po pierwsze, niemożność wykluczenia sytuacji, w której pomimo nałożenia na sprawcę wykroczenia środków oddziaływania wychowawczego został skierowany przez uprawniony organ wniosek o ukaranie, a po wtóre, ustawodawca podkreśla, wskazując na dyspozycję art. $61 \S 1$ k.p.w., że środki oddziaływania wychowawczego mogą być stosowane wyłącznie przed wszczęciem postępowania sądowego przez organ, który ujawnił wykroczenie, bądź przez inny uprawniony podmiot ${ }^{20}$. Także art. 5 k.p.w. nie wskazuje na wyłączenie prowadzenia postępowania, gdy wobec sprawcy zostały uprzednio zastosowane środki oddziaływania wychowawczego. Zdaje się jednak, że prowadzenie postępowania jurysdykcyjnego wobec sprawcy wykroczenia w takiej sytuacji jest niecelowe, nie jest jednak wykluczone. Prowadzenie postępowania przed sądem przy uprzednim zastosowaniu wobec sprawcy czynu środków oddziaływania wychowawczego byłoby jednak niespójne z samym sformułowaniem zawartym w art. 41 k.w., który wskazuje, że „wobec sprawcy czynu można poprzestać na zastosowaniu środków". Skoro zatem można poprzestać, należy wnioskować, że wobec tego konkretnego sprawcy nie mają sensu dalsze środki penalne, a środki oddziaływania wychowawczego będą uzasadnioną i wystarczającą do spełnienia celu postępowania reakcją na wykroczenie.

17 Tak I. Nowicka, R. Kupiński, Stosowanie środków oddziatywania wychowawczego w sprawach o wykroczenia, „Prokuratura i Prawo” 2004, nr 7-8, s. 147.

18 Tak R. Krajewski, Środki oddziaływania wychowawczego w prawie wykroczeń, „Palestra” 2013, nr 7-8, s. 19.

19 J. Jakubowska-Hara, op. cit., s. 313.

20 Tak T. Grzegorczyk, [w:] Kodeks wykroczeń, red. T. Grzegorczyk, Warszawa 2013, s. 180. 
Jak podnosi J. Jakubowska-Hara, orzekanie przed sądem w takiej sytuacji w istocie stwarzałoby możliwość dwuetapowej i dwurodzajowej reakcji ${ }^{21}$ państwa na wykroczenie. Uzasadniony jest zatem pogląd autorki, że należy postulować o modyfikację art. 5 k.p.w. przez stworzenie bezwzględnej przeszkody procesowej do wszczęcia bądź prowadzenia postępowania, gdy zastosowane zostaną uprzednio wobec sprawcy środki oddziaływania wychowawczego. Należałoby także wyraźnie wyartykułować priorytet stosowania środków pozakarnych wobec sprawcy wykroczenia, na przykład przez wskazanie, że organy postępowania w sprawach o wykroczenia mogą prowadzić postępowanie zmierzające do ukarania sprawcy wykroczenia tylko wtedy, gdy środki oddziaływania wychowawczego okazały się niewystarczające do wdrożenia go do poszanowania prawa ${ }^{22}$. Priorytetowe traktowanie środków oddziaływania wychowawczego stanowiłoby swoiste remedium na nadmiernie rygorystyczne wykorzystywanie formuły prawa wykroczeń do karania sprawców niektórych ich kategorii, a także mogłoby przyczynić się do zwiększenia autorytetu niektórych instytucji odpowiedzialnych za bezpieczeństwo i porządek publiczny, które niewątpliwie wiele wykroczeń narusza, ale nie zawsze w stopniu wymagającym karania, a jedynie w zakresie możliwym do poprzestania na zastosowaniu środków oddziaływania wychowawczego, co w szczególności wydaje się dotyczyć straży miejskich, które chyba niekiedy zapominają o swojej służebnej roli wobec społeczności lokalnych, na których rzecz powinny działać ${ }^{23}$.

Nieprecyzyjność przepisu 41 k.w. przejawia się także w nieokreśleniu kryteriów zastosowania środków oddziaływania wychowawczego jako reakcji na wykroczenie. Z samej treści przepisu wynika, że stosowanie tych środków możliwe jest za każde wykroczenie. W. Radecki podnosi, że organ upoważniony do złożenia wniosku o ukaranie czy do nałożenia grzywny mandatem karnym może zawsze, w sprawie o każde wykroczenie, bez zastanawiania się nad wystarczalnością środków oddziaływania i bez kontroli prokuratorskiej poprzestać na ich zastosowaniu ${ }^{24}$. M. Budyn-Kulik utrzymuje, że wykładnia celowościowa i systemowa art. 41 k.w. przemawia za tym, by na przesłanki stosowania środków oddziaływania wychowawczego patrzeć przez pryzmat art. 33 kodeksu wykroczeń. Można więc poprzestać na zastosowaniu środków oddziaływania wychowawczego, jeżeli spełnione będą cele kary, przede wszystkim w zakresie prewencji szczególnej, a nie należy po nie sięgać, gdy ze względu na społeczne oddziaływanie kary byłoby to niewłaściwe ${ }^{25}$. Nie bez znaczenia dla kryteriów oceny, kiedy zastosować środek oddziaływania wychowawczego, wydają się przesłanki leżące u podstaw złagodzenia kary, wskazane przez ustawodawcę w art. $33 \S 3$ k.w. Jako okoliczności łagodzące wymienia się w szczególności:

21 J. Jakubowska-Hara, op. cit., s. 317.

22 R. Krajewski, op. cit., s. 13.

23 Ibidem, s. 14.

24 W. Radecki, op. cit., s. 433.

25 Tak M. Budyn-Kulik, [w:] Kodeks wykroczeń. Komentarz, red. M. Budyn-Kulik et al., Warszawa 2009, s. 134-135. 
1. działanie sprawcy wykroczenia pod wpływem ciężkich warunków rodzinnych lub osobistych;

2. działanie sprawcy wykroczenia pod wpływem silnego wzburzenia wywołanego krzywdzącym stosunkiem do niego lub do innych osób;

3. działanie z pobudek zasługujących na uwzględnienie;

4. prowadzenie przez sprawcę nienagannego życia przed popełnieniem wykroczenia i wyróżnianie się wypełnianiem obowiązków, zwłaszcza w zakresie pracy;

5. przyczynienie się lub staranie się sprawcy o przyczynienie się do usunięcia szkodliwych następstw swego czynu.

Zaistnienie tych przesłanek winno dać sygnał uprawnionym organom, czy w danych okolicznościach karanie sprawcy jest niezbędne, czy też wystarczające będzie skorzystanie z innych pozakarnych środków reakcji. M. Bojarski wskazuje, że środki oddziaływania wychowawczego można zastosować, jeżeli będzie to wystarczające do wdrożenia sprawcy do poszanowania prawa i przestrzegania zasad współżycia społecznego ${ }^{26}$. Nie budzi wątpliwości, że środek pozakarny, a nie kara, winien być zastosowany wobec sprawcy czynu o niskiej społecznej szkodliwości. Zatem zgodnie z art. $47 \S 6 \mathrm{k}$.w. wpływ będą miały tu: rodzaj i charakter naruszonego dobra, rozmiary wyrządzonej lub grożącej szkody, sposób i okoliczności popełnienia czynu, waga naruszonego przez sprawcę obowiązku, a także postać zamiaru, motywacja sprawcy, rodzaj naruszonych reguł ostrożności oraz stopień ich naruszenia. Racjonalizując karanie sprawców wykroczeń, można uzasadnić, że podstawą do zastosowania środków oddziaływania wychowawczego będzie pozytywna prognoza kryminologiczna oraz niska społeczna szkodliwość popełnionego czynu. Jeżeli za zastosowaniem środków pozakarnych przemawia pozytywna prognoza kryminologiczna, a wykroczenie nie jest czynem o wysokiej społecznej szkodliwości, uprawniony organ powinien zastosować wobec sprawcy wykroczenia środki oddziaływania wychowawczego. Niemniej kryteria te nie są jasne i pozostają zależne od uznania funkcjonariuszy organów odpowiedzialnych za ściganie wykroczeń, co skutkuje niejednolitością w tym zakresie w takim znaczeniu, że w przypadku takich samych zachowań różnych sprawców jeden funkcjonariusz poprzestanie na zastosowaniu przedmiotowych środków, a inny nie, jak też możliwe jest, że ten sam przedstawiciel organu uprawnionego do postępowania w sprawach o wykroczenia raz uzna za stosowne poprzestanie na nich, innym razem nie, nawet gdy będzie miał do czynienia $\mathrm{z}$ analogicznymi wykroczeniami co do wszystkich szczegółów ich dotyczących ${ }^{27}$.

26 M. Bojarski, [w:] M. Bojarski, A. Płońska, Z. Świda, Podstawy materialnego i procesowego prawa o wykroczeniach, Wrocław 2012, s. 105. Takie kryterium zakłada także cytowane zarządzenie nr 323 Komendanta Głównego Policji z dnia 26 marca 2008 roku, które w § 9 wprost wskazuje na możliwość poprzestania na zastosowaniu środków oddziaływania wychowawczego, jeżeli jest to wystarczające do wdrożenia sprawcy do poszanowania zasad i współżycia społecznego.

27 R. Krajewski, op. cit., s. 15. 
Dookreślenie przesłanek umożliwiających zastosowanie środków oddziaływania wychowawczego znajdujemy w cytowanym zarządzeniu nr 323 Komendanta Głównego Policji z dnia 26 marca 2008 roku, w którym w $§ 10$ ust. 2 jako okoliczności uzasadniające zastosowanie środków oddziaływania wychowawczego, zatem wpływające na pozytywną prognozę kryminologiczną sprawcy, wymienione zostały w szczególności:

— przywrócenie stanu poprzedniego (na przykład uprzątnięcie wyrzuconych przez sprawcę przedmiotów zaśmiecających miejsce publiczne);

— naprawienie wyrządzonej szkody;

— przeproszenie pokrzywdzonego;

— zapewnienie ze strony sprawcy niepopełniania w przyszłości podobnego czynu zabronionego;

- wykonanie zaniechanego obowiązku (na przykład zaopatrzenie budynku w wymagany sprzęt przeciwpożarowy, tabliczkę z numerem porządkowym nieruchomości, uprzątnięcie terenu posesji itp.).

Katalog tych okoliczności nie jest zamknięty. Z. Kozicki podkreśla, że te same okoliczności wymienia ustawodawca w art. 39 § 4 k.w., przy czym o ile w ustawowym przepisie są one środkami oddziaływania społecznego, o tyle w cytowanym zarządzeniu są one przykładowymi przesłankami umożliwiającymi zastosowanie środków oddziaływania wychowawczego. W świetle przepisów zarządzenia dobrowolne wykonanie przez sprawcę wskazanych przykładowo czynności może uzasadniać zastosowanie środków oddziaływania wychowawczego ${ }^{28}$. Należy jednak zwrócić uwagę, że policja jest tylko jednym z podmiotów uprawnionych do stosowania tychże środków, inne zaś podmioty mogą kierować się zupełnie odrębnymi kryteriami warunkującymi zastosowanie środków oddziaływania wychowawczego.

Poza koniecznością ustalenia dodatniej prognozy co do sprawcy przy podejmowaniu decyzji o zastosowaniu środków oddziaływania wychowawczego przepis $\S 10$ ust. 4 zarządzenia wprowadza okoliczność, która uniemożliwia ich zastosowanie $^{29}$. Zgodnie z cytowanym przepisem nie stosuje się środków oddziaływania wychowawczego w wypadku wykroczeń, za które orzeka się środek karny. Dotyczy to zatem sytuacji, gdy wymierzenie środka karnego ma charakter obligatoryjny. Jeśli przepis ustawy daje jedynie możliwość orzeczenia środka karnego, można zastosować środek oddziaływania wychowawczego. Przesłanka ta winna znaleźć się także w zmodyfikowanym art. 41 k.w. Uzasadnione wydaje się, że środki oddziaływania wychowawczego nie powinny być stosowane również wtedy, gdy występują okoliczności obciążające wymienione w art. $33 \S 4$ k.w.

28 Z. Kozicki, Kilka uwag na temat stosowania przez Policję środków oddziaływania wychowawczego po zakończeniu czynności wyjaśniających, [w:] Reakcja Policji na popetnione wykroczenia - materiaty z konferencji, Szczytno 2008, s. 3, http://isp.policja.pl/isp/e-czytelnia/464,quotReakcja-Policji-na-popelnione-wykroczeniaquot-materialy-z-konferencji.html.

${ }_{29}$ M. Lis-Walewska, A. Mańko-Czajka, Środki oddziaływania wychowawczego stosowane wobec sprawcy wykroczenia, Legionowo 2013, s. 9. 
Niewątpliwie środki oddziaływania wychowawczego winny zostać utrzymane w kodeksie wykroczeń jako alternatywne wobec penalnych środki reakcji na wykroczenie, przede wszystkim wobec sprawców czynów o charakterze porządkowym (administracyjnym) o niskiej społecznej szkodliwości. Słusznie bowiem wskazuje M. Grudecki, że orzekanie w niektórych przypadkach kary wykroczeniowej jest lichym środkiem nauczenia człowieka szacunku do ładu społecznego i porządku prawnego ${ }^{30}$. Jednak niezbędna jest modyfikacja art. $41 \mathrm{k}$.w. ze względu na jego wątpliwości interpretacyjne. Należałoby dążyć do wyartykułowania w Kodeksie wykroczeń priorytetu środków oddziaływania wychowawczego nad penalnymi jako reakcji na wykroczenie oraz do ujednolicenia kryteriów stosowania tychże środków. R. Krajewski podkreśla, że subiektywizm w tym zakresie nie powinien być przecież podstawą rozstrzygnięć prawnych, a tymczasem różne okoliczności pozamerytoryczne mogą przesądzać o zastosowaniu bądź niezastosowaniu środków oddziaływania wychowawczego ${ }^{31}$. Niespełnienie ustawowego wymogu określoności i zupełności z pewnością utrudnia prawidłowe korzystanie z tej instytucji i stawia pod znakiem zapytania jej funkcję alternatywną wobec kary za wykroczenia ${ }^{32}$.

\title{
EXPEDIENCY OF EDUCATIONAL REACTION MEASURES IN PETTY OFFENCES LAW
}

\begin{abstract}
Summary
The law on petty offences includes both criminal and administrative acts. This forces the legislator to have a differentiated system of reaction. Next to strictly penal forms of impact on the petty offence perpetrator, the Petty Offenses Code allows the application of, among others, educational impact measures. The aim of this article is to present these measures, their application criteria and to emphasise the need for changes in the scope of Article 41 of the Petty Offences Code.
\end{abstract}

Keywords: a petty offence, educational impact measures, penal measures, non-criminal measures, public prosecutor

\section{BIBLIOGRAFIA}

Bojarski M., Płońska A., Świda Z., Podstawy materialnego i procesowego prawa o wykroczeniach, Wrocław 2012.

Budyn-Kulik M., [w:] Kodeks wykroczeń. Komentarz, red. M. Budyn-Kulik, P. Kozłowska-Kalisz, M. Kulik, M. Mozgawa, Warszawa 2009.

${ }^{30}$ M. Grudecki, Kara nagany i środki oddziaływania społecznego oraz środki oddziaływania wychowawczego w prawie wykroczeń, „Prokuratura i Prawo” 2018, nr 7-8, s. 189.

${ }^{31}$ R. Krajewski, op. cit., s. 15.

32 Tak J. Jakubowska-Hara, op. cit., s. 317. 
Grudecki M., Kara nagany i środki oddziaływania społecznego oraz środki oddziaływania wychowawczego w prawie wykroczeń, „Prokuratura i Prawo” 2018, nr 7-8.

Grzegorczyk T., [w:] Kodeks wykroczeń, red. T. Grzegorczyk, Warszawa 2013.

Gubiński A., Prawo wykroczeń, Warszawa 1980.

Jakubowska-Hara J., [w:] Reforma prawa wykroczeń, t. 1, red. P. Daniluk, Warszawa 2019.

Kodeks wykroczeń. Komentarz, red. M. Bojarski, W. Radecki, Warszawa 2019.

Kodeks wykroczeń. Komentarz, red. T. Grzegorczyk, Warszawa 2010.

Kotowski W., Kodeks wykroczeń. Komentarz, Warszawa 2009.

Kozicki Z., Kilka uwag na temat stosowania przez Policję środków oddziaływania wychowawczego po zakończeniu czynności wyjaśniających, [w:] Reakcja Policji na popetnione wykroczenia materialy z konferencji, Szczytno 2008, http://isp.policja.pl/isp/e-czytelnia/464,quotReakcjaPolicji-na-popelnione-wykroczeniaquot-materialy-z-konferencji.html.

Krajewski R., Środki oddziaływania wychowawczego w prawie wykroczeń, „Palestra” 2013, nr 7-8.

Lis-Walewska M., Mańko-Czajka A., Środki oddziaływania wychowawczego stosowane wobec sprawcy wykroczenia, Legionowo 2013.

Marek A., Prawo wykroczeń (materialne i procesowe), Warszawa 2012.

Nowicka I., Kupiński R., Stosowanie środków oddziatywania wychowawczego w sprawach o wykroczenia, „Prokuratura i Prawo” 2004, nr 7-8.

Radecki W., [w:] Kodeks wykroczeń. Komentarz, red. M. Bojarski, W. Radecki, Warszawa 2019.

Szumski J., Środki penalne w polskim prawie wykroczeń na tle doświadczeń praktyki, Lublin 1995. 